\title{
Effectiveness of Resources to Provide Health Care of National Health Insurance Participants Satisfaction: Meta-Analysis
}

\author{
Mumpuni Intan Pertiwi'), Muslihatin Khuril'), Okky Nurlita Sari3), Prajna Pramitha \\ Purba4), Raras Indung Palupis), Reza Ramadhana Tahta Firmansyah 6), Ruth \\ Apriyanti'7), Samara Rahma Dania' $^{8}$, Ulya Khoirunnisa' Atin 9), Winei Handriani'1o)
}

\author{
1)Health Polytechnic Ministry of Health Yogyakarta \\ ${ }^{2}$ Health Polytechnic Ministry of Health Surakarta \\ 3) Gadjah Mada University \\ 4) Jember State Polytechnic \\ 5)IIK Surya Mitra Husada Indonesia \\ 6) Jember University \\ 7)North Sumatra University \\ 8)Universitas Airlangga \\ 9)Universitas Muhammadiyah Surakarta \\ 10)Universitas Respati Yogyakarta
}

\section{ABSTRACT}

Background: Indonesia is one of the countries in the world that has a commitment to Universal Health Coverage in 2019. Indonesia has made various efforts to realize this commitment, one of which is through National health insurance. The presence of the National Administrative Body is new hope for the Indonesian people for the quality of health services that will be provided. The quality of service can be perceived as good and satisfies the patient if the service received is appropriate or exceeds what is expected. So it is necessary to apply a solution in training or training related to existing resources.

Subjects and Method: This study is a systematic review and meta-analysis. The articles used in this study were obtained from Pubmed and Scopus. The articles used in this research are articles published from 20162021. The article search was carried out by considering the eligibility criteria defined using the PICO model. P: JKN participants, I: adequate resources, C: insufficient resources, $\mathrm{O}$ : patient satisfaction. The articles included in this study are articles full text with a study design Cross-sectional. Articles were analyzed using the application Review Manager 5.3 .
Results: Funnel plot of comparisons showed a publication bias, as evidenced by the unbalanced number of plots on the left and right sides. The distance between the plots was far. Forest plot of national health insurance (JKN) patients with sufficient resources has 5.56 to experience patient satisfaction compared to patients with insufficient resources.

Conclusion: Publication bias in funnel plots is evidenced by the unbalanced number of left and right-sided plots. Whereas in the forest plot, JKN patients with adequate resources had a higher score, namely 5.56, to experience patient satisfaction than patients with inadequate resources. As a result, there are many complaints about the dissatisfaction of JKN participants with inadequate resources, so it is necessary to apply a solution in the form of training or training related to existing resources.

Keywords: Resources, Patient Satisfaction, JKN, Crossectional

\section{Correspondence:}

Mumpuni Intan Pertiwi. Health Polytechnic Ministry of Health Yogyakarta. Jl. Tata Bumi No. 3, DIY 55293, Central Java. Email: mumpuni.ip@gmail.com. Mobile: 085325638182 
Cite this as:

Pertiwi MI, Khuril M, Sari ON, Purba PP, Palupi RG, Throne RR, Apriyanti R, Dania SR, Khoirunnisa' U, Winei Handriani W (2021). Effectiveness of Resources to Provide Health Care of National Health Insurance Participants Satisfaction: Meta-Analysis. J Health Policy Manage. 06(02): 154-159. https://doi.org/10.26911/thejhpm.2021.06.02.08.

c) (†)(2) Journal of Health Policy and Management is licensed under a Creative Commons Attribution-NonCommercial-ShareAlike 4.o International License.

\section{BACKGROUND}

Indonesia is one of the countries in the world that has a commitment to Universal Health Coverage in 2019. Indonesia has made various efforts to realize this commitment, one of which has been done by the government is by organizing several National Health Insurance (Samsuddin ., 2019). The government has realized it through PT Askes (Persero) and PT Jamsostek (Persero) (Bannu, 2015). National health insurance is a form of government support for the health sector with a close relationship with socio-economic factors. According to Putra et al. (2019), those socio-economic factors are triggers for stressful events that lead to the emergence of various chronic diseases.

The government provides insurance through the Public Health Insurance (Jamkesmas) and Security Schemes for the poor and underprivileged. In general terms, services of the Social Security Administering Bodies (health BPJS) states that every participant has the right to health services, including First Level Outpatient health services (RJTP) and First Level Inpatient Care (RITP), Outpatient Health Services at the Advanced Level of RJTL), Advanced Level Inpatient Services (RITL), Emergency Services, and other health services stipulated by the minister. Health services are implemented in stages, starting from the first level of health services (Menkes RI, 2014).

The presence of the National Health Administration is new hope for the Indonesian people for the quality of health services that will be provided. The quality of service can be perceived as good and satisfies the patient if the service received is appropriate or exceeds what is expected. (Musdalifah et al., 2016).

Based on existing data on BPJS Kesehatan, there are 196.66 million participants in the National Health Insurance Program (JKN). Furthermore, this number is equivalent to $74 \%$ of the total population of Indonesia in 2018, which is estimated at 265 million people(Indonesian Ministry of Health., 2018).

A large number of BPJS users in Indonesia certainly requires adequate human resources. The requirements for human resources in health services, namely that they must have permanent personnel, medical personnel and medical support, nursing staff, pharmaceutical personnel, management personnel, and non-health workers. Every health worker who works in services must follow professional standards, hospital service standards, applicable standard operating procedures, professional ethics, and respecting patient rights. Therefore, this study focuses on resource effectiveness in providing health services to patient satisfaction of JKN participants by using a meta-analysis.

\section{SUBJECTS AND METHOD}

\section{Study Design}

The articles included in this study are fulltext articles with a Cross-sectional study design a systematic study using a MetaAnalysis approach. This study uses secondary data from the results of previous studies. Articles were obtained from databases, namely PubMed and Scopus. The 
keywords used are "Effectiveness" or "Usability" and "Resources" or "Potential" and "Patient Satisfaction" or "Patient Satisfaction" and "National Health Insurance" or "National Social Security System."

\section{Inclusion Criteria}

Articles included in this study were full text with designcross-sectional. The selected article discusses the relationship between resource effectiveness in providing health services and patient satisfaction with JKN participants. The articles are published in Indonesian. The study sample was patients using JKN. Study locations in Indonesia. Obesity Articles should be published in 2016-2021. Multivariate learning outcome data. The final results of the study are reported using the Adjust Odds Ratio (aOR).

\section{Exclusion Criteria}

Articles excluded in this study were articles with the RCT, case-control, quasi-experimental, and research protocol research design. Statistical results do not report the adjusted odds ratio for outcome variables.

\section{Operational Definition of Variables} Search for articles was carried out by considering the eligibility criteria defined using the PICO model. The population in the study was JKN participants. The intervention in this research is Adequate Resources: the comparison, namely Inadequate Resources and Outcomes, namely Patient Satisfaction.

Health insurance is a national social security program based on social insurance and equity principles to ensure that participants receive health care benefits and protection in meeting primary health needs.

Patient satisfaction is the patient's expectation or response in receiving health services.

\section{Data Analysis Data}

processing was carried out by the Review Manager (RevMan 5.3) by calculating the effect size and heterogeneity to determine which research models were combined to form the final meta-analysis result.

\section{Study Variables}

This was meta-analysis research with the theme Effectiveness of resources to provide health care of patient satisfaction of participants JKN: a meta-analysis. Independent variable The presence of the National Administration Agency is new hope for the Indonesian people for the quality of health services that will be provided. The quality of service can be perceived as good and satisfying the patient if the service received is following or exceeds what is expected. So it is necessary to apply a solution in training or training related to existing resources.

The dependent variable has many complaints about JKN participants' dissatisfaction with inadequate resources, so it is necessary to apply a solution in training or training related to existing resources. The study design used in cross-sectional articles.

\section{Instrument of Study}

The stages of this research follow the PRISMA Flow diagram and the assessment of the quality of search articles using the Critical Appraisal Skills Program CASP) for a Cross-sectional study.

\section{RESULTS}

Systematic review and meta-analysis took the topic of the effectiveness of resources in providing health services on the satisfaction of JKN participant patients. The dependent variable is the satisfaction of JKN participant patients. The factors used in the independent variables in this study are resources. This study discusses the satisfaction of JKN participant patients with health service resources. 
Pertiwi et al./ Effectiveness of Resources to Provide Health Care of National Health

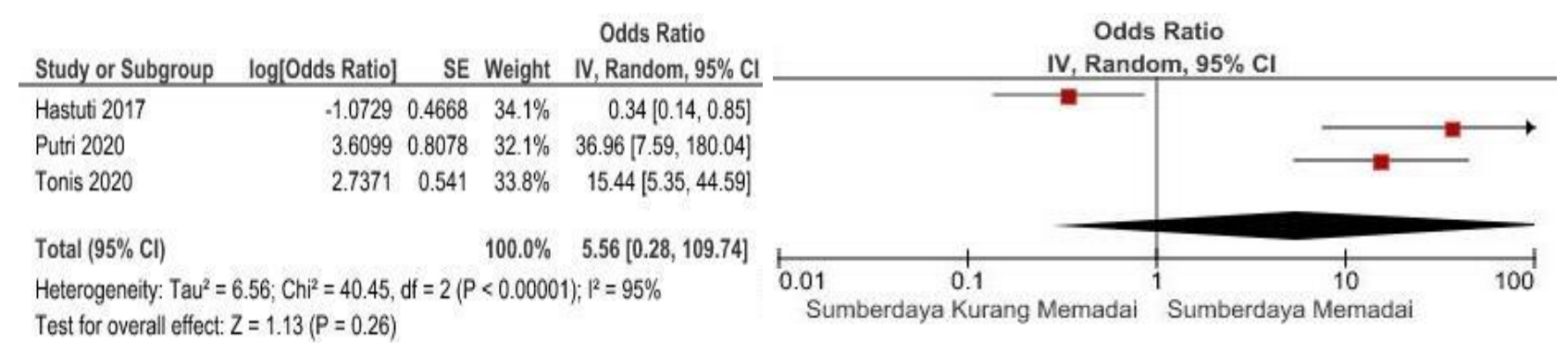

Figure 1. Forest Plot

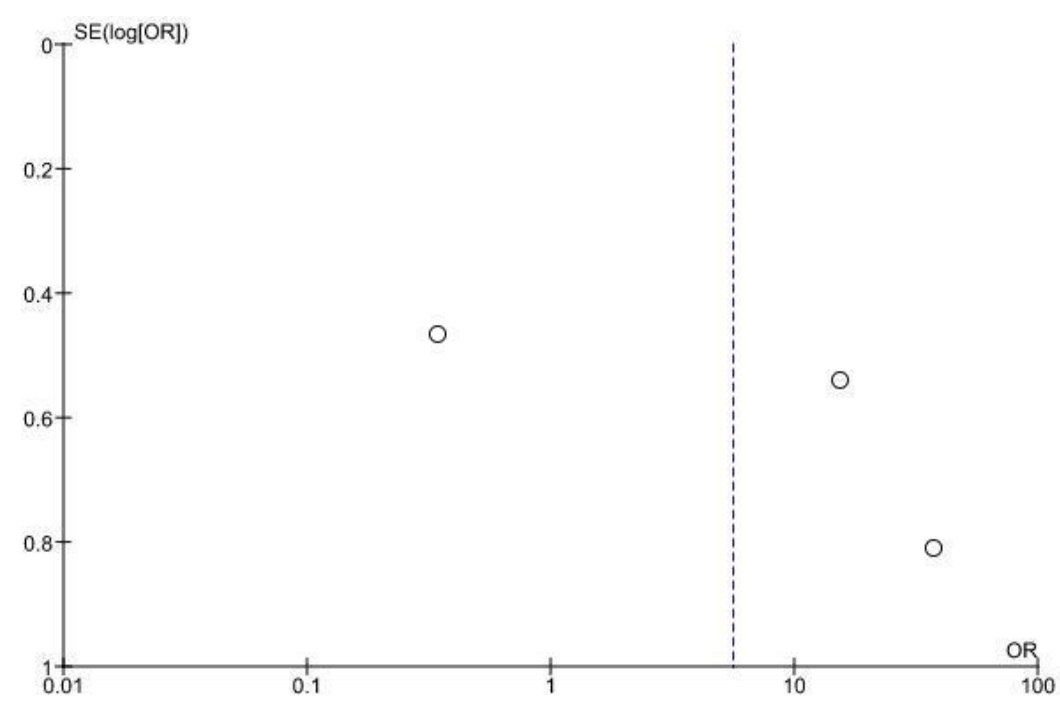

Figure 1. Funnel Plot

The preliminary study results used for meta-data analysis were collected from various countries and in large sample sizes to increase the heterogeneity of research results. The results of the meta-analysis are informed of the funnel plot and a forest plot. The funnel plot of comparison shows the existence of publication bias, as evidenced by the number of plots on the left and right sides is not balanced. The distance between plots is far. Forest plot JKN patients with sufficient resources have 5.56 to experience patient satisfaction than patients with insufficient resources.

There are three articles as a source of meta-analysis of JKN participant patient satisfaction with health service resources. Primary articles that have met the requirements are then analyzed using the
Review Manager 5.3 program. Data analysis was carried out one by one to find out about the satisfaction of JKN participant patients with health service resources. (OR 5.56; CI $95 \% 0.28$ to $109.74 ; \mathrm{p}=0.260$ ) Heterogeneity $\mathrm{I}^{2}=95 \%$.

\section{DISCUSSION}

The effectiveness of resources in providing health services to patient satisfaction of JKN participants

Most studies show JKN patient dissatisfaction with health services (Putri et al., 2020; Tonis et al., 2020; Hestuti et al., 2017). Several reasons could support the dissatisfaction of JKN participant patients with health services. First, officers do not want to serve, and officers are selective in 
providing services related to patient satisfaction with JKN participants.

Health services are the rights of every person guaranteed in the 1945 Constitution of the Republic of Indonesia which must be realized by efforts to improve the highest public health status (RI Law No. 44 of 2009). Therefore, to increase public health as high as possible, it is necessary to develop health services. Health Management is an activity or art to organize health workers and non-health workers to improve public health through health programs. In other words, public health management is the application of general management in the public health service system, so that the object and target of management is the public health service system (Tonis et al., 2020).

Indonesia is one of the countries in the world that has a commitment to Universal Health Coverage in 2019. The commitment made will have a positive impact on Indonesian citizens to get the health service coverage they need. Indonesia has made significant efforts to realize this commitment through the National Health Insurance (Putri et al., 2020). Social Security Administering Bodies (BPJS) are public legal entities established to administer social security programs. The BPJS consists of BPJS Kesehatan and BPJS Ketenagakerjaan. BPJS Kesehatan is a legal entity established to administer a health insurance program. Health insurance is a guarantee in the form of health protection so that participants get the benefits of health care and protection in meeting primary health needs provided to everyone who has paid dues or whose contributions are paid by the government (Kemenkes RI 2013).

The weakness of this study is that we included 1 article with less than 100 respondents from Tonis et al. (2021) with 88 respondents who contributed to publi- cation bias. In addition, all major studies in this meta-analysis did not describe the instruments used to assess JKN participant satisfaction and increase the risk of bias.

This study can provide an overview that health insurance still shows the dissatisfaction of patients who receive health services. Several factors cause satisfaction with the health services provided by health workers.

\section{AUTHOR CONTRIBUTION}

All researchers collected and selected eligible articles, ran the Revman 5.3 program for meta-analysis, and wrote the paper.

\section{CONFLICT OF INTEREST}

There is no conflict of interest in this research.

\section{FUNDING AND SPONSORSHIP}

This study used a personal fund from the researcher.

\section{ACKNOWLEDGEIMENT}

This study used a personal fund from the researcher.

\section{REFERENCE}

Bannu P (2015). The Relationship Between Perceptions of BPJS Health Services and Patient Satisfaction at RSUP DR. Moh. Hoesin Palembang.

Hastuti, Mudayana, Nurdhila, Hadiyatma, D (2017). Relationship of service quality with patient satisfaction of BPJS participants at Yogyakarta Regional General Hospital. J Public Health, 11(2): 161-168.

RI Ministry of Health (2013). Handbook of Socialization of National Health Insurance (JKN) in the National Social Security System. 
Minister of Health(2014). Regulation of the Minister of Health of the Republic of Indonesia Number 28 of 2014 concerning Guidelines for Implementation of the National Health Insurance Program

Muzdalifah, Irwandy, Maidin A (2016). Analysis of Differences in Satisfaction of JKN and General Patients in Bantaeng Hospital. Indones $\mathrm{J}$ of Health Policy. 05(01): 1-34.

Notoatmodjo S(2012). Health Research Methodology. Jakarta: Rineka.

Putra M, Widiyanto A, Winduyasa B, Atmojo J (2019). The relationship of socio-economic conditions and stress levels with the incidence of hypertension. Journal of Nursing Intan Husada. 07(02): 1-13.

Putri, Nurhayati, Zulfikar (2020). Factors Related to Patient Satisfaction with BPJS Services. Real in Nursing Journal. 3(2): 68-76. http://dx.doi.org/10.32883/rnj.v3i2.839.g313.

Samsuddin H, Ningsih ER (2019). Quality of Service for Outpatient Satisfaction of Dr. Mohammad Hoesin Central General Hospital, Palembang. Journal of Ecoment Global. 4 (1): 63.

Tonis M, Wiranata R(2021). Hubungan mutu pelayanan kesehatan dengan kepuasan pasien rawat inap peserta BPJS kesehatan di RSUD Selasih Pangkalan Kerinci Kabupaten Pelalawan tahun 2015 (Related quality of health services hospital patient satisfaction with participants in health BPJS Hospital Selasih Pangkalan Kerinci District Pelalawan Year 2015). Jurnal Administrasi Rumah Sakit. 1 (1). https://media.neliti.com/media/publications/319052-hubungan-mutu-pelayanan-kesehatan-dengan-2ccb2a58.pdf.

Law of the Republic of Indonesia Number 44 Year 2009. About the Hospital: paragraph 5 section (1), paragraph 20, paragraph $28 \mathrm{H}$ section (1), and paragraph 34 section (3) The Constitution of the Republic of Indonesia of 1945. 